\title{
STILISTIKA NILAI EDUKATIF QUOTE KHR. AHMAD AZAIM IBRAHIMY
}

\begin{abstract}
Oleh:
Yulia Tutik Nurfia \& Miftahul Alimin

Universitas Ibrahimy

raisyarahmana3011@gmail.com \& alimin92miftahul@gmail.com

Abstract:

This research is based on the style used by KHR. Ahmad Azaim Ibrahimy through his snippet of da'wah (quote) that has interesting style of languages, education messages delivered simply but so attractive. The aim of this research was to analyze and to study the language style of quotes used by KHR. Ahmad Azaim Ibrahimy in religion speech and the implementation in running his function in Pondok Pesantren Syalafi'iyah-Syafi'iyah. The research approach used was descriptive qualitative that focused on analytics and didactics. Data collection method had used the textual data analysis in language style of KHR. Ahmad Azaim Ibrahimy. The research result showed that in language style of KHR. Ahmad Azaim Ibrahimy there were metaphor, personification, allegory, irony, association, simile, metonymies, euphemism, and pleonasm figures of speech. The messages of the quotes can be understood by the readers, especially the students and the alumni of Pondok Pesantren Syalafi'iyahSyafi'iyah.
\end{abstract}

Keywords: Stalistika, Nilai Edukatif, Kiai Pesantren, KHR. Ahmad Azaim

\section{A. Pendahuluan}

Gaya tidak dapat dipisahkan dengan pemakain Bahasa. Sudjiman, menerjemahkan gaya bahasa itu sendiri mencakup diksi, struktur kalimat, majas dan citraan, pola rima, serta mantra yang digunakan seorang. Stilistika merupakan ilmu tentang gaya (style), meliputi berbagai cara yang dilakukan dalam kegiatan manusia ${ }^{1}$. Style merupakan efek seni dan dipengaruhi oleh keadaan jiwa penulis/pembicara. Melalui style seorang pembicara dapat menuangkan idenya, pengungkapan ide yang diciptakan

1 I Nyoman Kutha Ratna, Stilistika: Kajian Puitika Bahasa, Sastra, dan Budaya, (Yogyakarta: PT Pustaka Pelajar, 2009), 167. 
melalui keindahan dengan bahasa. Sehingga, dengan ide tersebut pembicara dapat membentuk konsep gagasan yang menghasilkan penggunaan bahasa dan gaya bahasa (diksi, struktur kalimat, majas dan citraan, pola rima) yang mampu mempengaruhi jalan pikiran seseorang sebagai efek tertentu. Kajian bahwa masih banyak pembaca quote khususnya para santri dan alumni belum maksimal mengamalkan isi quote KHR. Ahmad Azaim Ibrahimy sesuai dengan norma agama dan nilai-nilai pendidikan yang terkandung di dalamnya.

Beberapa bukti bahwasanya santri maupun alumni tidak mengamalkan nilai-nilai pendidikan yang terkandung dalam quote tersebut yaitu: merosotnya nilai adab santri yang ditandai dengan kurangnya kesopanan santri ketika masuk ke dalam kelas dan cara berbahasa santri yang terkontaminasi gaya berbahasa modern. Bentuk lain, kekhasan berbahasa dapat diperlihatkan oleh salah satu kiai di Jawa Timur dalam berdakwah. KHR. Ahmad Azaim Ibrahimy melalui penggalan dakwahnya (quote) memiliki kekhasan gaya bahasa yang sangat menarik. Nilai merupakan sesuatu yang abstrak, yang dijadikan pedoman serta prinsip-prinsip umum dalam bertindak dan berperilaku. Keterikatan seseorang terhadap nilai sangatlah kuat, bahkan bersifat emosional. Dengan kata lain, nilai dapat dilihat sebagai tujuan hidup manusia itu sendiri. Selain itu nilai merupakan sesuatu yang berharga. Hal itu juga selaras dengan pendapat Kosasih menyatakan bahwa nilai adalah sesuatu yang penting dan berguna atau bermanfaat bagi manusia ${ }^{2}$.

Penggalan atau nukilan teks dakwah tersebut memiliki khasanah pesan pendidikan yang dikemas dengan gaya bahasa yang sederhana namun sangat memikat. KHR. Ahmad Azaim Ibrahimy sangat lihai menggunakan pemilihan bahasa untuk menyampaikan isi dakwahnya. Penggalan dakwah KHR. Ahmad Azaim Ibrahimy ini memiliki kekhasan yang tidak ditemukan dalam dakwah-dakwah kiai di Jawa Timur khusnya. Mengkaji permasalahn tersebut diperlukan sebuah pengkajian nilai-nilai pendidikan yang telah ditanamkan KHR. Ahmad Azaim Ibrahimy bermuara pada style isi quote dan implementasi nilai pendidikan yang terkandung dalam quote KHR. Ahmad Azaim Ibrahimy.

Nilai edukatif (berbudi pekerti luhur) dikatakan sebagai pembiasaan untuk hidup bersopan santun, bertata karma secara benar, baik dalam perkataan maupun dalam perbuatan, berdisiplin, dan memiliki 46.

${ }^{2}$ Kosasih E, Dasar- Dasar Keterampilan Bersastra, (Bandung: Yrama Widya, 2012),

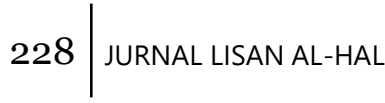


rasa hormat yang tinggi ${ }^{3}$. Berdasarkan pengertian tersebut, edukatif adalah hal- hal penting yang dapat menuntun manusia dalam tumbuh kembangnya hingga mencapai pada kedewasaan jasmani dan rohani. Nilai agama merupakan konsep mengenai penghargaan yang tinggi yang diberikan kepada warga masyarakat pada beberapa masalah pokok dalam kehidupan keagamaan yang bersifat suci sehingga menjadikan pedoman bagi tingkah laku keagamaan warga msyarakat yang bersangkutan ${ }^{4}$. Dapat disimpulkan nilai-nilai pendidikan yang telah ditanamkan KHR. Ahmad Azaim Ibrahimy bermuara pada style isi quote sebagai konsep yang dimiliki manusia terhadap kepercayaan dan keyakinan terhadap Tuhan dalam kehidupan yang terkait dengan hubungan antara manusia dengan Tuhan serta hubungan perilaku antarsesama manusia dan lingkungan.

Tujuan penelitian ini mendeskripsikan gaya bahasa (style) quote yang digunakan serta implementasi quote KHR. Ahmad Azaim Ibrahimy terhadap para pembaca khususnya para santri dan alumni Pondok Pesantren Syalafi'iyah-Syafi'iyah. Hasil kajian diharapkan mampu memberikan pengetahuan mahasiswa terhadap gaya bahasa dan implementasi nilai edukatif yang terkandung dalam quate KHR. Ahmad Azaim Ibrahimy. Kemanfaatan lain, citivitas akademika (dosen, guru, pengajar) mendapatkan wawasan bahan refrensi terkait kajian gaya bahasa (style).

\section{B. Metode}

Penelitian ini memanfaatkan penelitian lapangan (meneliti teks) dan penelitian perpustakaan yang secara khusus meneliti teks, baik lama maupun baru berupa gaya bahasa (style) quote KHR. Ahmad Azaim Ibrahimy5. Pendekatan didaktis yang berusaha menemukan dan memahami gagasan, tanggapan evaluative maupun sikap digunakan dalam menganalisis quote Ibrahimy terhadap kehidupan terhadap gagasan, tanggapan maupun sikapnya yang mampu mewujudkan suatu pandangan etis, filosofis, maupun agamis sehingga terkandung nilai-nilai yang mampu

3 Basuki dkk., Pedoman Penciptaan Suasana Sekolah yang Kondusif dalam Rangka Pembudayaan Budi Pekerti Luhur Bagi Warga Sekolah, (Jakarta: Dirjen Dikdasmen Depdiknas, 2013), 1.

4 Depdiknas, (KBBI) Kamus Besar Bahasa Indonesia, (Jakarta: PT Balai Pustaka, 2007), 783.

5 I Nyoman Kutha Ratna, Stilistika: Kajian Puitika Bahasa, Sastra, dan Budaya, (Yogyakarta: PT Pustaka Pelajar, 2009), 39. 
memperkaya kehidupan rohaniah para santri dan alumni Pondok Pesantren Syalafi'iyah-Syafi'iyah.

Penelitian memfokuskan pada gaya bahasa style dan nilai pendidikan moral-religius yang ditentukan. Fokus gaya bahasa style terkait majas metafora, personifikasi, alegori, ironi, asosiasi, simile, metonomia, eufemisme, dan majas pleonasme. Data yang berupa Isi media (quote) KHR. Ahmad Azaim Ibrahimy yang cukup popular di medsos ini dipahami, diidentifikasi, dianalisis, dan diinterpretasikan oleh peneliti sebagai instrument kunci. Pengumpulan data penelitian dilakukan dengan teknik observasi teks dan dokumentasi. Teknik observasi berupa pengamatan secara mendalam terhadap data alamiah, yaitu "Quote KHR. Ahmad Azaim Ibrahimy". Teknik dokumentasi dilakukan dengan mendokumentasikan temuan data dalam table pengumpulan data (korpus data) sesuai dengan klasifikasi hasil kajian penelitian.

Adapun prosedur pengumpulan data dilakukan dengan mencari, membaca quote KH. Ahmad Azaim Ibrahimy dengan intensif dan mencatat jenis majas dan nilai yang merupakan fokus kajian. Data yang ditemukan dimasukan dalam table pengumpulan data, dilakukan kodefikasi terhadap temuan. Pendeskripsian sesuai klasifikasi selanjutnya proses evaluasi sebagai bagian editing. Secara teoritis kajian kualitatif analisis data ditempuh dengan 3 tahap yaitu reduksi data, sajian data, dan penarikan simpulan $^{6}$. Ketiga langkah ini tidak dilaksanakan secara bertahap selalu diikuti dengan hasil, misalnya reduksi data sekaligus juga penarikan simpulan. Dapat juga terjadi pengumpulan data sekaligus dengan analisis data, misalnya dengan memasukkan ke dalam klasifikasi tertentu.

Analisisis data dilakukan dengan analisis konten terhadapkontekskonteks yang terdapat pada objek penelitian yaitu analisis terhadap teks alamiah, yaitu "Quote KH. Ahmad Azaim Ibrahimy". Analisis kontens digunakan untuk memahami quote dari aspek ekstrinsik. Aspek- aspek yang mencangkup di dalamnya yaitu nilai moral dan nilai religi. Selanjutnya dilakuukan interpretasi untuk menemukan dan mendeskripsikan gaya bahasa (style) quote yang digunakan KHR. Ahmad Azaim Ibrahimy serta implementasinya terhadap para pembaca khususnya para santri dan alumni Pondok Pesantren Syalafi'iyahSyafi'iyah.

${ }^{6}$ Moleong Lexy J, Metode Penelitian Kualitatif Edisi Revisi (PT Remaja Rosdakarya: Bandung, 2005), 219.

$230 \mid$ JURNAL LISAN AL-HAL 


\section{Hasil Dan Pembahasan}

\section{Gaya Bahasa (Style) Quote KHR. Ahmad Azaim Ibrahimy}

Style dapat diartikan sebagai cara khas yang dipergunakan oleh seseorang untuk mengutarakan atau mengungkapkan diri atau gaya pribadi. Pengertian style sangat luas, bisa meliputi style sekelompok pengarang, style suatu bangsa, style perseorangan, dapat juga merupakan style pada periode tertentu atau gaya penulisan tertentu ${ }^{7}$. Stilistika tidak hanya merupakan studi gaya bahasa dalam kesusastraan saja, tetapi juga studi gaya dalam bahasa pada umumnya meskipun ada perhatian khusus pada bahasa kesusastraan yang paling sadar dan paling kompleks. Stilistika berguna untuk membeberkan kesan pemakaian susun kata dalam kalimat yang menyebabkan gaya kalimat, di samping ketepatan pemilihan kata, memegang peranan penting dalam ciptaan sastra. Sudjiman berkesimpulan bahwa style dapat diterjemahkan sebagai gaya bahasa. Gaya bahasa itu sendiri mencakup diksi, struktur kalimat, majas dan citraan, pola rima, serta mantra yang digunakan seorang pengarang atau yang terdapat dalam sebuah karya sastra ${ }^{8}$. Menurut Keraf, gaya bahasa meliputi semua hierarki kebahasaan, yakni pilihan kata (diksi), frasa, klausa, dan kalimat, serta wacana ${ }^{9}$. Senada dengan itu, Pradopo menyatakan bahwa unsur-unsur gaya bahasa itu meliputi: (1) intonasi, (2) bunyi, (3) kata, (4) kalimat, dan (5) wacana.

Kata style (bahasa Inggris) berasal dari kata Latin stilus yang berarti alat (berujung tajam) yang dipakai untuk menulis diatas lempengan lilin. Perlu kita ketahui bahwa gaya bahasa (style), sesuai dengan konteks kajiannya yakni karya sastra yang bermediumkan bahasa, style diartikan sebagai 'gaya bahasa'. Gaya bahasa adalah cara pemakaian bahasa dalam karangan, atau bagaimana seorang pengarang mengungkapkan sesuatu yang akan dikemukakan ${ }^{10}$. Menurut Leech \& Short ${ }^{11}$, style menyaran pada cara pemakaian Bahasa dalam konteks tertentu, oleh pengarang tertentu, untuk tujuan tertentu.

Data temuan pada quote KHR Ahmad Azaim Ibrahimy tampak pada pengunaan tata Bahasa bermajas metafora pada MM1- RE/1. Pada kalimat

\footnotetext{
${ }^{7}$ Soediro Satoto, Stilistika (Yogyakarta: Ombak, 2012), hlm 36

${ }^{8}$ Gorys Keraf, Gaya Bahasa dan Diksi (Jakarta: PT. Gramedia Pustaka Utama, 2010), 99.

${ }^{9}$ Gorys Keraf, Gaya Bahasa dan Diksi.... 112.

10 M.H. Abrams, A Glossary of Literary Terms. (New York: Holt, Rinehart and Winston. 1981), 190-191.

11 Geoffrey N Leech. dan Michael H. Short. Style in Fiction. (London and New York: Longman. 1984), 10.
} 
ini, "Tiada akan mampu seseorang mensifati baginda Nabi Muhammad, melainkan dihatinya ada rasa Mahabbah (Cinta) yang sangat kuat". Pada quote tersebut mengumpamakan cinta (mahabbah) Nabi Muhammad yang tidak dapat ditandingi oleh manusia manapun kepada Allah SWT. Kecuali, seorang hamba (manusia) benar- benar memiliki rasa yang kuat yakni cinta mahabbah. Ahmad Zain menggunakan Bahasa perbanding metafora, sebagai gaya Bahasa yang menggunakan analogi atau perumpamaan terhadap hal yang berbeda. Bahasa berkias dengan tujuan untuk menghidupkan atau meningkatkan efek yang menimbulkan konotasi tertentu yang mampu memperlihatkan jiwa dan kepribadian lebih atas kata yang dimaksud dan ditekankannya. Dalam konteks tersebut Ahmad Zain berusaha menjabarkan ide yang termaktub dalam teks sehingga bersesuaian dengan tujuan tausiah sehingga menimbulkan efek yang ingin dituju.

Gaya Bahasa metaphor juga tampak pada teks nukilan MM1-RE/2, "Tidak semua orang memiliki kapasitas: قَلَبَك إِنْنَفْتِ (Mintalah nasihat baik, kepada hatimu) hanya orang- orang yang memiliki keimanan terbaik, hatinya bisa memberi nasehat. Dalam quote ini Ahamd Azaim Ibrahimy hendaknya meminta nasihat kepada hati individu dengan cacatan manusia/individu tersebut memiliki tingkatan keimanan yang baik sehingga kata hati dapat memberi nasihat yang terbaik untuk diri individu. Penggunaan gaya bahasa ini beliau hendak memberikan penekanan analogi sebagai gaya Bahasa yang tersampaikan secara jujur, memberika daya tarik dan penuh kesopanan pada penekanan makna religius. Ahmad Zain ingin memberikan karakteristik yang berbeda dengan yang lain, sehingga menciptakan efek religious yang lebih hidup dan berasa pada pendengar/pembaca serta lebih efektif.

Pada sisi metafora berbahasa yang digunakan Ahmad Zain pada penekanan efek moral tampak pada MMI-MO/1 yakni "Kemaksiatan yang sebenarnya bermasalah, akan menjadi biasa-biasa saja ketika dipertontonkan setiap saat. Ini tantangan berat, fitnah zaman media sosial saat ini". Pada nukilan ini Ahmad Zain ingin mengungkapkan bahwa begitu mudahnya semua orang mengakses media social mempermudah semua kalangan tua maupun muda berselancar di dunia maya. Mereka tak malumalu lagi mempertontonkan aurat, tarian, dan suara emasnya. Berburu subscribe menjadi pemantik berbagai usia untuk mengumbar kemaksiatan. Akibat dari hal tersebut yakni "fitnah zaman media social" yang menganggap kemaksiatan biasa- biasa saja namun, menurut KHR. Azaim Ibrahimy hal tersebut adalah tantangan yang sangat berat. Pada

$232 \mid$ JURNAL LISAN AL-HAL 
MMI-M0/2, "Riya' adalah " As- syirik Al- Ashghar" atau bentuk syirik yang samar didalam hati. Sebab seharusnya ia berbuat semata karena Allah. Ia rendahkan nilainya dengan mencari". Dalam nukilan ini analogi riya' dirupakan penyakit hati yang tidak terlihat dengan mata. Riya' dapat dirasa dengan mata hati seseorang. Manusia pamer atas rutinitas ibadah yang dilakukannya dan segala bentuk kebaikannya di media sosial. Tanpa mereka sadari memicu manusia menanggapinya dengan berbagai tanggapan baik positif maupun negative. Akibatnya, nilai ibadah yang seharusnya semata untuk Allah SWT terlihat rendah nilainya karena "Assyirik Al- Ashghar" syirik yang samar. Dalam penggunaan gaya bahasa ini Ahmad Zain mencoba menciptakan intensitas perasaan pembaca/pendengar dalam sebuah pemaknaan dan sikap. Mengkonsentrasikan pemakanaan yang hendak disampaikan dengan caracara bahasa majas yang singkat padat.

Penggunaan gaya bahasa lain tampak pada penggunaan majas personifikasi, yang memberikan efek kereligiusan serta bermakna moral. Data terkait quote moral terdeskripsi pada MPER-RE/1, yakni "Puncak Keimanan Adalah Sabar...". Dalam quote tersebut Ahmad Azaim Ibrahimy menjelaskan bahwa semesta diciptakan dengan ketulusan cinta. seperti akar yang tak terlihat tapi memberikan anugerah atau penopang hidup pepohonan. Akar disini berfungsi sebagai perbandingan dengan manusia yang memiliki cinta, memberi manfaat kepada orang lain tanpa harus terlihat perbuatan baik kita sebagai seorang muslim. Pada MPER-RE/2, mendeskripsikan hal terkait tasbih. Dikatakan bahwa Tasbih adalah salah satu bentuk alat berdzikir untuk memuliakan Allah SWT. Tasbih dijadikan alat perbandingan sebagai jalan menuju seseorang beribadah dan beramal baik. Menurut KH. Ahmad yang Azaim Ibrahimy "tasbih memberikan keberkahan tersendiri bagi seseorang beramal shalih dan mampu mengantarkan seseorang kepada derajat lebih tinggi."12

Deskripsi penggunaan majas personifikasi efek moral gaya berbahasa sebagai bagian dari style quote KHR. Ahmad Azaim Ibrahimy tampak pada MPER-MO/1 yakni "Semesta dicipta dengan cinta. Cinta adalah ketulusan dan ketulusan adalah cinta itu sendiri. Mengajilah kepada akar yang telah dengam susah payah memberi segala anugerah untuk pepohonan tanpa harus terlihat ke permukaan tanah". Pada deskripsi ini dikatakan bahwa ibadah merupakan perbuatan berbakti kepada Allah SWT dengan menjalankal segala perintahnya dan menjauhi

${ }^{12}$ Majlis Dzikir Basmalah, 12/02/2021. 
larangannya. Suatu emosi dalam cinta diharapkankan mampu memberikan stimulus dan motivasi seseorang dalam melaksanakan segala kewajibannya. Dengan cinta, seseorang akan mampu melaksanakan ibadahnya tanpa rasa beban. Sifat majas sebagai bagaian gaya Bahasa pada adsarnya menghubungkan satu hal dengan yang lain sehingga menjadi menarik perhatian yang menimbulkan kesegaran hidup terutama saat menimbulkan kejelasan gambaran yang diinginkan atau disampaikan. Personifikasi yang merupakan gaya Bahasa kias mampu menggambarkan sebagai sifat kemanusiaan. Kemampuan Ahmad Azaim dalam memanupulasi atau memanfaatkan usnsur dan kaidah yang terdapat dalam Bahasa mampu menimbulkan efek yang baik dalam penggunaannya. Gaya Bahasa yang digunakan dengan situasi dan kondisi yang baik mampu menyampaikan pesan dengan cara imajinatif sehingga mampu memberikan efek emosional pembaca/pendengar.

Bentuk gaya Bahasa lain yang dipergunakan Ahmad Azaim Ibrahimy tampak pada kodifikasi MAS-RE dan MAS-MO dengan gaya selingkung majas asosiasi yang menyatakan kemaknaan nilai religious dan moral bagi pembaca/pendengarnya. Pada MAS-RE/1,"istiqomah adalah cara ampuh melawan penyakit Riyâ' (pamer)". Dikatakan bahwa Istiqomah dan riya' merupakan dua kata berbeda dan memiliki ari yang berbeda pula. Dua kata tersebut memiliki hubungan yang keberadaannya dapat mengisi yang satu dengan yang lainnya. Sikap konsisten dalam mengerjakan sesuatu disebut dengan istiqomah. Jika seseorang dalam beribadah selalu mengamalkan keistiqomahannya maka akan terbebas penyakit Riya' (pamer) di dalam hatinya yang memberikan perangkat pekerti pada sisi nilai religious seseorang". Dan pada MAS-M0/1, "orang hebat adalah orang yang pandai menyimpan, merahasiakan cintanya yang dahsyat". Pada sisi ini, factual pekerti tentang moral berusaha ditekankan melalui kalimat assosiasi. Dimaknakan cinta merupakan suatu rasa yang dianugerahkan oleh Allah SWT kepada makhluknya agar senantiasa tidak saling menyakiti satu dengan yang lain. Pernyataan cinta yang dahsyat pada seorang hamba sholih tidak harus diungkapkan secara berlebihan. Hal itu dapat menciptakan caci maki terhadap suatu kelompok fanatisme. Hanya diri mu'min yang hebatlah yang mampu menyimpan dan merahasiakan cintanya di dalam hati. Sehingga tercipta kondusifitas dalam bermasyarakat.

Struktur batin dan struktur lahir, yang identik dengan isi dan bentuk dalam gaya bahasa tampak pada gaya bahasa yang digunakan Ahmad Azaim Ibrahimy. Struktur lahir ini meruapakan performansi 
kebahasaan dalam wujudnya yang konkret, dan itulah gaya bahasa. Adapun struktur batin merupakan gagasan yang ingin dikemukakan oleh Ahmad Azaim Ibrahimy melalui gaya bahasanya. Style 'gaya bahasa' yang merupakan cara gagasan dan perasaan dengan bahasa khas sesuai dengan kreativitas, kepribadian, dan karakter pembicara untuk mencapai efek tertentu, yakni efek estetik atau efek kepuitisan dan efek penciptaan makna semakin tampak. Gaya bahasa ini dipakai Ahmad Azaim sebagai sarana retorika dengan mengekploitasi dan memanipulasi potensi Bahasa, sarana kepuitisan yang berupa muslihat pikiran.

Dalam quote KHR, Azaim Ibrahimy juga terdeskripsi penggunaan gaya Bahasa bermajas ironi. Kenampakan majas ini terurai pada MI-RE yang bertanda nilai-nilai pekerti religious dan MI-MO yang bernuansa pekerti nilai moral. Pada MI-ME/2, "Tanda orang yang dibenci Allâh, adalah mereka yang membenci Takdir Allâh", misanya, pada teks ini tersirat makna takdir sebagai ketetapan Allah SWT. Manusia diberikan kesempatan untuk mengubah takdir yang telah di gariskan sedangkan hasil akhirnya pasrahkan saja kepada Allah SWT (takdir muallaq). Seperti firman Allah SWT dalam surah Ar- Ra'du ayat 11 yang artinya: “... Sesungguhnya Allah SWT tidak akan mengubah keadaan suatu kaum sebelum mereka mengubah keadaan diri mereka sendiri".

Namun sebaliknya, Allah SWT membenci seorang mu'min yang membenci ketetapan takdir yang telah Allah SWT berikan. Selanjutnya pada MI-RE/5, "Jangan mempertanyakan takdir yang buruk kepada Allâh, tapi pelajarilah Hikmah dari hal itu". Pada pemaknaan ini bahwa Segala yang terjadi di dunia ini merupakan ketetapan Allah SWT, seperti adanya siang dan malam, adanya musibah dan bencana alam. Sebagai seorang hamba beriman harus menerima takdir yang telah digariskan kepadanya. Seringkali manusia tidak menerima keadaan dan menyalahkan takdir Allah SWT yang salah terhadap dirinya. Tidak seharusnya seorang hamba beriman mempertanyakan takdir buruk yang menimpanya. Hendaknya merenungkan dan mengambil hikmah dari musibah yang telah menimpanya.

Gaya bahasa atau style dalam quote Ahmad Azaim ini dikatakan sebagai olah pemanfaatan atas kekayaan bahasa dalam bertutur dengan pemakaian ragam tertentu untuk memperoleh efek-efek tertentu. Keseluruhan ciri-ciri bahasa yang digunakakannya merupakan cara khas dalam menyatakan pikiran dan perasaan. Gaya bahasanya bermakna cara mengungkapkan pikiran melalui majas Bahasa yang secara khas memperlihatkanxjiwa dan kepribadiannya. Implementasi penggunaan gaya bahasa tersebut memungkinkan dapat menilai pribadi, watak, dan 
kemampuan seseorang yakni Ahmad Azaim Ibrahimy dalam menggunakan bahasa dalam quotenya. Data penggunaan majas ironi bernuansa nilai pekerti moral salah satunya juga tampak pada MI-MO/2. Majas sindiran sebagai upaya menyembunyikan kefaktaan dalam mengatakan hal yang sebaliknya. "Tugas seorang Santri adalah membersihkan diri dari Akhlaq yang kotor. Ketika seorang Santri masih kotor karakter perilaku dan ucapannya, sejatinya ia belum pantas disebut seorang Santri Sejati (طَلِبُ

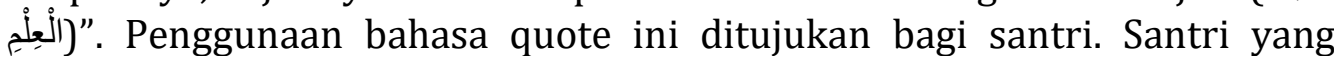
harus bersih dari perbuatan kotor. Selayaknya, jika seorang santri masih memiliki pikiran, perilaku, dan ucapannya kotor maka santri tersebut belum pantas disebut dengan santri sejati.

Gaya bahasa sebagai pembungkus pikiran, ide ini selalu hadir dalam benak Ahmad Azaimi Ibrahimy yang selalu memanfaatkan ide-ide pemikiran dalam setiap tausiyahnya. Bungkusan bahasa yang khas membuat santri memiliki kekhasan atau keunikan tersendiri dalam menilai dan memahami kyainya sebagai ketaklangsungan ekspresi. Ketaklangsungan ekspresi dalam Quote KH. Ahmad Azaim Ibrahimy disebabkan adanya tiga hal, yakni: penggantian arti (displacing of meaning) dilakukan dengan penggunaan misal metafora atau metonimia; penyimpangan arti (distorting of meaning) disebabkan oleh adanya pemakaian misalnya makna ambiguitas, kontradiksi; dan penciptaan arti (creating of meaning) yaitu pengorganisasian teks. Gaya bahasa mencakup diksi atau pilihan leksikal, struktur kalimat, majas dan citraan, pola rima memberikan nuansa pola piker pekerti yang berkesan bagi para santri.

Jelas bahwa gaya bahasa bukan sekedar saluran saja, tetapi alat yang menggerakkan sekaligus menyusun kembali dunia sosial itu sendiri. Gaya bahasa baik bagi penulis maupun pembaca berfungsi untuk mengeksplorasi kemampuan berbahasa khususnya bahasa yang digunakan dalam bertausiyah. Stilistika dikatakan sebuah proses memperkaya cara berpikir, cara pemahaman, dan cara perolehan terhadap substansi kultural. Melalui gaya bahasa pembaca dapat menilai kepribadian dan kemampuan Ahmad Azaimi Ibrahimy, semakin baik gaya bahasa yang digunakan, semakin baik pula penilaian terhadapnya. Sering dikatakan bahwa bahasa adalah karakter budi pekerti dan watak psikologis yang terekam dalam perilaku yang dihasilkannya.

\section{Implementasi Quote KHR. Ahmad Azaim Ibrahimy}

Implementasi dikatakan sebagai proses untuk memastikan terlaksananya suatu kebijakan dan tercapainya suatu projek yang 
diterapkan yang memberikan efek lanjut pada proses projek tersebut. Impelementasi dimaksudkan menyediakan sarana untuk membuat sesuatu dan memberikan hasil yang bersifat praktis terhadap sesama. Pelaksanaan sebagai serangkaian kegiatan dalam rangka untuk memberikan perubahan pola pikir sehingga pemampatan terhadap tindakan ini dapat membawa hasil, seperti yang diharapkan. Implementasi berupa kegiatan, tindakan, atau mekanisme sistem yang tidak hanya berupa aktivitas, tetapi kegiatan dan untuk mencapai tujuan dari kegiatan yang direncanakan.

Jadi implementasi dimaksudkan sebagai tindakan individu publik yang diarahkan pada tujuan serta memberikan hasil yang bersifat praktis terhadap sesama. Sehingga dapat tercapainya sebuah kebijakan yang memeberikan hasil terhadap tindakan- tindakan individu publik dan swasta. Implementasi dari Quote KHR. Ahmad Azaim Ibrahimy diperoleh berdasarkan hasil koesener yang diberikan beberapa stake holder dan santri, sebagai berikut. Bahwa dari koesener terkait (1) ciri khas dalam berdakwah, terdapat $96,67 \%$ menyatakan ya, belum tahu 3,33\%, tidak dan tidak paham sebesar 0\%; (2) berdakwah dengan penawaran cara millennial di dapat 93,33\% menyatakan ya, tidak tahu 3,33\%, belum tahu sebesar 3,33\%, dan tidak paham sebesar 0\%; (3) pemahaman santri/stake holder terhadap pemahaman isi quote dikatahui 100\% memahami, sedang tidak tahu,belum tahu dan tidak paham 0\%; (4) terkait isi quote berisi pesan moral didapat prosentase $93,33 \%$ menyatakan ya, 3,33\% tidak, $3,33 \%$ belum tahu, dan tidak paham 0\%; (5) isi quote berisi pesan religious menyatakan data $100 \%$ ya, lainya $0 \%$; (6) isi quote berisi nilai moral bagi santri/alumni/simpatisan menyatakan data $100 \%$ kategori ya, tidak-belum tahu-tidak paham 0\%; (7) isi quote berisi nilai religius bagi santri/alumni/simpatisan menyatakan data 100\% kategori ya, tidakbelum tahu-tidak paham 0\%; dan hasil capain koesener terhadap efek dari quote kyai adalah 30 orang menyatakan sepakat bahwa isi dakwah KHR. Ahmad Azaim Ibrahimy memberikan kemanfaatan yang berkesan terhadap kehidupan anda sehari-hari. Hal ini terbukti dari pengakuan koesener yakni "sangat bermanfaat, iya bermanfaat karna yang diajarkan beliau selalu tentang kebaikann yang bisa kita amalkan di kehidupan sehari-hari, sangat berpengaruh sekali, merupakan pedoman bagi para santri termasuk saya sendiri, sperti lebih baik terus berbuat baik daripada melihat kejelekan orang lain, iya sangat berpengaruh untuk meneladani dawuh-dawuhnya, memberikan pedoman dan bimbingan, dan bermanfaat untuk bisa menjadi manusia yang lebih baik lagi". Selanjutnya koesener menyatakan bahwa sosok kyai satu ini berbudi pekerti alim, santun, \begin{tabular}{l|l} 
JURNAL LISAN AL-HAL & 237
\end{tabular} 
berwibawa, rendah hati, sesok yabg sangat lantas menjadi teladan para santri, alumni dan simpatisan, berwibawa,,sabar,,alim,,,, tawadhu', 'alim, sabar, lemah lembut, karismatik.. alim... dan penuh inspirasi, bersahaja, suritauladan, penuh cinta pada umat, beliau (khr. ahmad azaim ibrahimy) merupakan sosok yang sangat inspiratif, sosok teladan bagi kami dalam segala hal dan dalam kehidupan sehari-hari, terlihat dari beberapa dakwah yang beliau berikan kalau kh. Ahmad Azaim Ibrahimy sangat friendly terutama dikalangan anak muda. Beliau juga tegas dan tidak kolot terhadap jaman milenial., dan beliau adalah sosok tokoh yang dapat mengayomi semua golongan. Dalam banyak kesempatan selalu berpedoman ada nilai-nilai religius hingga masalah manajemen pesantren.

\section{Simpulan}

Gaya Bahasa berfungsi sebagai alat untuk meyakinkan atau mempengaruhi pembaca atau pendengar. Gaya bahasa juga berkaitan dengan situasi dan suasana pengarang. Dengan demikian, dapat dikemukakan bahwa fungsi gaya bahasa dalam karya sastra sebagai alat untuk: (1) meninggikan selera, artinya dapat meningkatkan minat pembaca/pendengar untuk mengikuti apa yang disampaikan pembicara; (2) mempengaruhi atau meyakinkan pembaca atau pendengar, artinya dapat membuat pembaca semakin yakin dan mantap terhadap apa yang disampaikan pembicara; (3) menciptakan keadaan perasaan hati tertentu, artinya dapat membawa pembaca hanyut dalam suasana hati tertentu, seperti kesan baik atau buruk, perasaan senagn atau tidak senang, benci, dan sebagainya setelah menangkap apa yang dikemukakan pengarang; selanjutnya (4) memperkuat efek terhadap gagasan, yakni dapat membuat pembaca/pendengar terkesan oleh gagasan yang disampaikan.

Dalam kedudukannya sebagai teori dan pendekatan penelitian yang berorientasi linguistic (dengan parameter linguistik), maka dapat dikatakan bahwa stilistika dalam Quote KH. Ahmad Azaim Ibrahimy ini mampu menghubungkan perhatian para santri dalam apresiasi estetik dengan perhatian linguis dalam deskripsi linguistic; terdapatnya proses kajian bagaimana unsur-unsur bahasa mampu menghasilkan pesan-pesan aktual lewat pola-pola yang digunakan dalam quote. Ketiga, stilistika mampu menghubungkan intuisi-intuisi tentang makna-makna dengan pola-pola bahasa dalam teks yang dianalisis; stilistika untuk menuntun pemahaman yang lebih baik terhadap makna yang dikemukakan; stilistika untuk menemukan prinsip-prinsip artistik yang mendasari pemilihan Bahasa seseorang. Kajian stilistika akan menemukan kiat 
memanfaatkan Bahasa sabagai sarana pengungkapan makna dan efek estetik nilai pekerti. Dalam mengungkapkan setiap pemikiran membutuhkan bahasa yang dapat dengan mudah dimengerti oleh orang lain, dan gaya bahasa merupakan alat yang unik.

\section{DAFTAR PUSTAKA}

Abrams, M.H. A Glossary of Literary Terms. New York: Holt, Rinehart and Winston. 1981.

Amalia, Novita Rihi. Analisis Gaya Bahasa dan Nilai-Nilai Pendidikan Novel Sang Pemimpi Karya Andrea Hirata, Skripsi, Universitas Sebelas Maret, 2010.

Aminuddin, Stilistika Pengantar Memahami Bahasa dalam Karya Sastra, Semarang: IKIP Semarang Press, 2013.

Arba'ie, Sujud dan Arbak Othman. 2014. Stilistika. Selangor Darul Ehsan: Penerbit Universiti Putra Malaysia.

Basuki, Pedoman Penciptaan Suasana Sekolah yang Kondusif dalam Rangka Pembudayaan Budi Pekerti Luhur Bagi Warga Sekolah, Jakarta: Dirjen Dikdasmen Depdiknas, 2013.

Depdiknas, (KBBI) Kamus Besar Bahasa Indonesia, Jakarta: PT Balai Pustaka, 2007.

Endraswara, Suwardi. Metodologi Penelitian Sastra, Yogyakarta: CAPS, 2011.

Endraswara, Suwardi. Metodologi Penelitian Sastra: Epistemologi, model Teori, dan Aplikasi. Yogyakarta: CAPS (Center for Academic Publishing Service), 2013.

HB Sutopo, Metodologi Penelitian Kualitatif: Dasar Teori dan Terapannya dalam Penelitian, Surakarta: Universitas Sebelas Maret, 2006.

Jakob, Sumardjo dan Saini, Apresiasi Kesusastraan, Jakarta: PT. Gramedia Pustaka Utama, 1997.

Jauhari, Heri. Panduan Penulisan Skripsi Teori dan Aplikasi, Bandung: Pustaka Setia, 2010.

Kemendiknas, Makalah, Pengembangan Pendidikan dan Budaya Karakter Bangsa, Jakarta: Kemendiknas, 2010.

Keraf, Gorys. Diksi dan Gaya Bahasa, Jakarta: Gramedia Pustaka, 2007.

Keraf, Gorys. Gaya Bahasa dan Diksi, Jakarta: PT. Gramedia Pustaka Utama, 2010

Kosasih, Dasar-Dasar Keterampilan Bersastra, Bandung: Yrama Widya, 2012.

Leech, Geoffrey N dan Michael H. Short. Style in Fiction. London and New JURNAL LISAN AL-HAL $\mid 239$ 
York: Longman. 1984.

M Sumantri, Pendidikan Umum, Bandung: Imperial Bhakti Utama, 2007.

Miles. Mathew dan Michael Huberman, Analisis Data Kualitatif Buku Sumber Tentang Metode- Metode Baru, Jakarta: UIP, 1992.

Mujiyanto, Yant. Analisis Stilistika dan Nilai Pendidikan Novel Bumi Cinta Karya Habiburrahman El Shirazy, Jurnal Basastra, Vol. 1 No. 1, Desember 2012.

Muslich, Mansur. Latihan Apresiasi Sastra. Penunjang Pengajaran Bahasa dan Sastra Indonesia, Surabaya: Triana Media, 2013.

Nurgiayantoro, Burhan. Teori Pengkajian Fiksi, Yogyakarta: Gajah Mada University Press, 2010.

Nurhayati, Teori dan Stilistik, Surakarta: Unsri, 2008.

Rampan, Korrie Layun. Apresiasi Cerpen Indonesia Mutakhir, Jakarta: Bukupop, 2009.

Ratna, I Nyoman Khuta, Stilistika: Kajian Budaya. Puitika, Sastra, dan Pelajar, Yogyakarta: Pustaka, 2014.

Ratna, I Nyoman Khuta. Stilistika: Kajian Puitika Bahasa, Sastra, dan Budaya, Yogyakarta: PT Pustaka Pelajar, 2009.

Satoto, Soediro. Stilistika, Yogyakarta: Ombak, 2012.

Subroto, Edi. Pengantar Metode Penelitian Linguistik Struktural, Surakarta: UNS Press, 1992.

Supriyanto, Teguh. Stilistika dalam Prosa. Pusat Bahasa Departemen Pendidikan Nasional, Jakarta, 2009.

Tarigan, Guntur. Pengajaran Bahasa, Bandung: Angkasa, 2009.

Varima, Rika Nila. Analisis Nilai-Nilai Pendidikan Naskah Drama Bunga Semerah Darah Karya W. S. Rendra, Artikel e- journal Universitas Maritim Raja Ali haji, 2017.

Zainal, Abdul Rozak Zainal, Kamus Istilah Ssatra, Jakarta: Balai Pustaka, 2007.

$240 \mid$ JURNAL LISAN AL-HAL 